\title{
The Impact of Social Media in Political Participation Among Students in Nigeria
}

\author{
Temple Uwalaka \\ News and Media Research Center, University of Canberra, Canberra, Australia
}

Email address:

temple.uwalaka@canberra.edu.au

\section{To cite this article:}

Temple Uwalaka. The Impact of Social Media in Political Participation Among Students in Nigeria. Humanities and Social Sciences. Vol. 9, No. 5, 2021, pp. 145-154. doi: 10.11648/j.hss.20210905.13

Received: August 19, 2021; Accepted: September 8, 2021; Published: September 15, 2021

\begin{abstract}
The invention and rapid development of information and communication technologies (ICTs) has attracted considerable attention in theoretical and practical debates about the role of digital media in political participation. With the emergence of digital media, people in nascent democracies such as Nigeria have started using their online presence to engage in political discussions. This has led to an increase in political protests in undemocratic and developing democracies. While majority of previous digital activism and political communication research suggests positive relationships between digital media diffusion and socio-political protests, there is little research investigating the impact of social media use in digitally organised protest to long term political participation and efficacy formation, particularly in young democracies such as Nigeria. This study bridges that gap in the literature. The aim of this study is to examine the impact of social media use, and protest experience, in political participation and efficacy formation among students in Nigeria. This study reports on a sequential explanatory mixed methods approach, consisting of a 680 face-to-face paper survey response and 34 semi-structured qualitative interviews of university students in Nigeria. Findings show that protest experience, and political efficacy significantly increased students' intention to join politics more than social media. Of the variables, political efficacy was the strongest predictor of intention to participate in politics. In addition, the study demonstrates that the experience of collective and connective actions increases the likelihood of further political participation among students in Nigeria. This study concludes with a proposed flowchart of political efficacy formation among students in Nigeria.
\end{abstract}

Keywords: Digital Activism, Nigeria, Political Participation, Political Efficacy, Social Media, Social Movements

\section{Introduction}

Citizens' perception and interest in democratic practices and political participation are crucial to democratic governance [19]. While this is true for all democracies, it carries greater consequence for young democracies such as Nigeria. This is because political participation and engagement not only guarantees the nourishment of democracies but also strengthens the credentials of popular rule in young democracies [1, 19]. Studies have indicated that social media diffusion fosters political participation in nascent democracies and autocratic regimes [12]. These political participations come most times from protests. Researchers have equally attributed the recent increase in collective and connective actions across the globe (for example, the Occupy Movements, the 2011 Arab Spring, the $15 \mathrm{M}$ in Spain, and the 2012 Occupy Nigeria protest) to increase in digital media platforms [12]. These platforms enable these collective actions by supplying mobilizing information, propagating enthusiasm and enabling emotional contagion $[5,6,25,26,72,71,68]$.

Despite an abundance of research investigating social media effects on political participation, most of the existing research has been conducted in advance western democracies, and increasingly in Asia [5, 7, 8]. Limited inquiry has evaluated the association between social media use and political participation in Sub-Saharan Africa. Also, fewer studies have investigated the interrelationship between social media use, protest experience, and political participation in young African democracies such as Nigeria. Social movements studies have also failed to investigate the impact of protests to political participation and efficacy formation. While it is important to study these social movements, the more germane impetus should be to uncover the impact of 
such protest in bringing about political participation and interests in medium to long term democratic processes in countries such as Nigeria that recently returned to democracy.

The current study aims to address this gap and expand knowledge in this area through the examination of the impact of social media use, protest experience and political participation and efficacy formation among students in Nigeria. The study further interrogates interests in democratic governance processes for students with protest experience and those without protest experience. To this end, using a cross sectional survey and semi-structured interview data, this study evaluates the impact of social media use, protest experience and political participation and efficacy formation among students in Nigeria.

\section{Background of the Study}

Nigeria is a West African country of about 200 million people [48]. Nigeria became a colony of Britain in 1800 and achieved self-government in 1960. Until independence in 1960, Nigeria used the mass media for political activism. This mass-mediated political activism culture was introduced during the nationalists' struggle for self-rule. Writers such as Ernest Ikoli and Nnamdi Azikiwe used the mass media (newspaper) to engage in political activism [2, 3, 66, 58] but the seizure of political power by the military in post-colonial Nigeria stifled freedom of expression and press freedom suffered $[3,54,55,56]$. The resultant military dictatorship caused many Nigerians to avoid visibly participating in political discourse [2. 3, 55]. However, this appears to be changing with recent protests such as the 2012 Occupy Nigeria protests, the failed 2016 protest in Nigeria, the 2020 \#EndSARS protest in Nigeria and many more. This study is based on three of such recent protests.

On January 1, 2012, then President Goodluck Jonathan announced the cessation of subsidy on Premium Motor Spirit (PMS) [53]. Nigerians were enraged with the government for the PMS subsidy removal because of years of perceived abandonment of Nigeria's refineries. As a result of the President's New Year announcement, prices of basic goods and services increased by up to 120 percent and this provoked a protest movement referred to as 'The 2012 Occupy Nigeria' $[15,16,21]$. The protest lasted for about a month and took place in all the major cities in Nigeria. The protest stopped when the government partially reinstated the subsidy after a dialogue with the leadership of the Nigeria Labour Congress (NLC).

In April of 2014, 276 female students from Chibok Secondary School, Chibok, Bornu State, Nigeria, were kidnapped by Boko Haram, a terrorist organisation in northern Nigeria. The silence of the Nigerian Government sparked outrage across Nigeria and many other parts of the world. This outrage led to the creation of the hashtag, '\#bringbackourgirls'. The hashtag went viral and has since morphed into a protest organisation in Nigeria. The hashtag virality and subsequent protests in Nigeria helped force the Nigerian government into acknowledging the abduction and provide modalities for the rescue mission that ensued. Many of the girls have been successfully rescued.

The 2015 'social media' bill also known as frivolous petitions bill was sponsored by Senator Ibn Na'Allah. The bill stipulates two years imprisonment, a fine of two million Naira or both for anyone who, through text messages, tweets, WhatsApp or any other social media platforms, post critical comments of a person, group of persons or an institution of government. The bill also made it unlawful to submit petitions, statements intended to report the conduct of people for the purpose of an investigation without a duly sworn affidavit in a court. The bill scaled through second reading in December 1, 2015 and then was moved to the committee level. There was a public hearing regarding the bill in March 2016. Activists in Nigeria joined forces to call for the withdrawal of the bill which they claimed will limit freedom of expression in Nigeria. After sustained criticism, the senate withdrew the bill in May 17, 2016.

While digital activism studies in Nigeria [29, 31, 36, 68, 70, 72-74] have demonstrated that internet technologies positively contributed to the planning and organizing of these protests, none has interrogated the impacted of such protests on Nigerians in the medium and long terms, particularly how such protests influence political efficacy formation in Nigeria. This study attempts to bridge that gap. The paper is interested in knowing how social media use and protest experience impacted the political psyche of Nigerian students. Consequently, this paper examines the impact of social media use, protest experience in political participation and political efficacy formation among Nigerian students. The paper attempts to answer the following research question:

To what extent do Nigerian students' social media use, protest experience, and political efficacy predict their intention to participate in politics?

What is the perception of government accountability among university students in Nigeria?

\section{Literature Review}

In this section, the researcher reviews communication literature by first evaluating the relationship between digital media and political participation. After looking at digital media and political participation, the study then examines results from other studies regarding the impart of digital media in political efficacy formations.

\subsection{Digital Media and Political Participation}

More than a few numbers of early research in political communication [64] revealed a negative correlation between the digital media and political participation in the United States of America. Putnam [61] said that Americans were 'bowling alone' and that this was impacting political participation and democracy. Amongst the perpetrators to this damaging development in America were television and digital media. The study found that technology clearly correlate with the breakdown of social capital, implying that technology, together with other variables, was depleting the 
lives of the American people and their communities. Likewise, McChesney [42-44] contends that free enterprise is turning the digital media against democracy and that online political participation was destroying activism. Fenton and colleague [22] claim that far from being empowering, that the logic of self-centred participation encouraged by social media can represent a threat for political groups rather than an opportunity as it does not focus on how technology and technology use are framed by political issues and issues that concern the development of society. Such issues according to Fuchs [24] include capitalist crises, profit interest, global war, the globalization of capitalism, or the rise of a surveillance society.

In contrast, researchers [27, 30, 33] state that internet users are drawn to some forms of democratic knowledge and participation. Digital media was successful in exposing Americans to a broader political perspective [30], while certain sectors of the American population who did not normally engage offline, engaged in politics through the internet $[27,33]$.

The role of the internet in democracy, particularly in young democracies, is to provide pluralistic competition, participatory, and political liberties for those who feel stifled in mainstream politics [49-52]. Increase in internet usage allows for greater communication and better access to information. This in turn increases political participation and democratic governance [62].

Loader and his colleagues [39] provided novel insights into the role of participatory media in young people's process of becoming politically engaged. They suggest a robust positive association between the internet and political engagement among young people across the USA, Australia, and the UK while Vitak and colleagues [77] say that student political activity online was an important predictor of other forms of political participation. It can also be argued that online media use positively associates with higher levels of political participation [78]. It has been confirmed that effective participation in the communication of political information online strongly impact political efficacy [45].

Internet technologies, particularly social media, have been found to perform a crucial role during presidential elections in the United States of America [63, 69]. Studies revealed that internet access, and online exposure to information about presidential elections in countries such as the USA was significantly associated with political efficacy and participation. The internet and its technologies do not only increase users' online political participation; but also help offline participation. It is imperative to note that internet usage alone is unlikely to radically transform existing patterns of political participation, it may however, facilitate the creation of new pathways for engagement. Researchers contend that there is an association between internet skills, social media usage and greater levels of political participation, and that online political expression enhances the effects of offline political participation [28, 81].

Studies have also demonstrated how digital media and its technologies have facilitated political participation and civic engagement in Africa. Also, it has been stated that uncomplicated, inexpensive, and cost-effective ICT tools are being used to mobilize, and to trigger the intuitiveness, belligerence of local citizens' participation in good governance process in Western Uganda [4]. Similarly, Kanjo [32] argues that an experience-based model that promotes the use of multiple ICTs enhances citizen's democratic participation in low-ICT resource countries as online platforms have the potential to increase citizen's political participation and engagement leading to social movements and protests. Furthermore, Oyesomi and colleagues [59] observed that social media technologies, particularly Facebook were used to a remarkable extent by Nigerian political aspirants in mustering the support of the electorate and assisting the electorate to participate during the election. However, the mobilization and participation were limited to those "who had internet or mobile phones with internet applications' [59]. Social media has also been argued to enhance social capital and political participation as well as engagement of youths in Nigeria and other countries such as Kenya and the USA, particularly during the period of national elections $[47,69]$. In effect, the internet enhances political participation and engagement to a great extent and is a new avenue for participation especially for the marginalized groups.

\subsection{Digital Media and Political Efficacy}

Substantial internet and political participation studies [80, 34] link information seeking behaviour, and motivation to an increase in political efficacy and political participation. Political efficacy is described as a sense that 'political and social change is possible, and that the individual citizen can play a part in bringing about this change' [11]. Information seeking has been associated with online political information connection and political efficacy [34, 41]. Seeing social connectedness as a gratification of social media use was positively associated with political efficacy among college students in China [80].

The importance of political efficacy to the sustenance of democratic beliefs and ideals are increasingly being examined. Researchers [41, 60] have looked at the effect of information about politics, entertainment, and education to the formation and increase in political efficacy of individuals. For example, participants who reported higher informational uses of their Smartphones also reported greater political efficacy [60]. Similarly, Martin and his coleagues [41] showed that the strongest predictors of political efficacy were print media use, reliability of online information, media credibility, and tolerance of free speech. This is also similar to previous results. For example, traditional newspaper use, and social media use for political communication have been stated to be predictors of political efficacy [45] internet exposure and access have been noted to have positively associated with a sense of political efficacy among citizens during elections [35].

The use of the internet for political purposes positively predicts political efficacy among Tunisian internet users [9]. 
From the foregoing, it is apparent that political efficacy is crucial to the maintenance of citizens participation in politics. Hence, studying the effects of social media use, protest experience, and political participation and efficacy formation become salient. A common theme in this review is the US background of much of these studies, necessitating the present study. This study makes a significant contribution in the area of political communication as it provides empirical results from a developing democracy from Sub-Saharan African country with a mixed methods data.

\section{Methods}

This paper embraces a sequential explanatory mixedmethods research approach. Mixed methods research refers to studies that integrate elements of qualitative and quantitative approaches to improve the understanding of a phenomenon of interest and corroborate the findings [10]. Sequential explanatory mixed method approach is an approach in which quantitative data will be collected and analysed first, before embarking on qualitative data collection as the second phase of data collection is intended to explicate certain drawbacks of the quantitative result [18]. The choice of mixed methods for this project was because the questions used dichotomous variables, thus, there was the need for several data sources so as to 'offset' [10]. The study reports on response from mixed methods research consisting of response from 680 purposive cross-sectional face-to-face, paper-based survey and 34 semi-structured qualitative interviews of students from the University of Lagos, Lagos State and the Rivers State University, Port Harcourt, Rivers State, Nigeria. These two universities are in two liberal and heterogeneous cities in Nigeria with student and residential populations that cut across ethnicity and religion. The participants were a mix of undergraduate and postgraduate students. The first phase of the survey was collected in 2015 $(\mathrm{N}=440)$, and the second phase was collected in 2018 $(\mathrm{N}=240)$. Phase one targeted those that participated in the 2012 Occupy Nigeria protest while phase two targeted those that participated in the \#bringbackourgirls and \#antisocialmediabill campaigns. University students are more likely to join a protest by themselves than being "coerced" by their union. That is, students in Nigeria would generally not have an association that urged them to be involved in a protest as would some others, such as: teachers, lecturers, lawyers, civil servants, and doctors, who may be given directives "offline" to participate by their respective unions and associations.

The survey consists of eight sections covering perceived government accountability, perceived corruption level, perceived competitiveness of political participation, political efficacy, intention to participate in politics, social media use, and protest experience. The researcher used a mix of dichotomous (yes - no) scales and five-point Likert type scale (" $1=$ strongly disagree", " $2=$ Disagree", " $3=$ neutral", "4=agree", and "5=strongly agree"). Perceived government accountability (Cronbach's alpha.725) was adapted from Freedom House democracy score questions [23, 38]; political efficacy (Cronbach's alpha.880) and intention to participate in politics (Cronbach's alpha.883) were adopted from the work of $[35,46,64]$ respectively.

Social media use was measured by asking about the respondents' social media use frequency. That is, how frequent respondents use social media. The researcher measured this by asking respondents how often they use social media on a 6-point Likert type scale, with scores ranging from 'never', 'every second month', 'every few weeks'. 1-2 days a week', 'about once a day' and 'several times a day' (coded $0,1,2,3,4$, and 5 respectively). Finally, protest experience was measured as a dichotomous variable (yes $=1$, and $n o=0$ ). Protest experience was measured by asking about respondents' participation in any of the three protests online or offline on a "yes" or "no" pattern. The responses were then aggregated into 0 for "no" and 1 for "yes".

After analyzing the survey data, the researcher conducted 34 semi-structured interviews, that is, 19 interviews in 2015, and 15. Thematic and meaning condensation approaches were adopted to make sense of the data. At its essence, the approach rephrases what is said by participants into just few words of a more succinct nature, but in which the meaning is not lost. The purpose is to allow the researcher to go 'beyond what is directly said to work out structures and relations of meaning not immediately apparent in a text' $[18,37]$. This allowed the researcher to use themes, and add subjective interpretations to the data, based on what the meaning is perceived to be from the experience undergone during the interview.

\section{Results}

The participants in this study were mainly between 22 to 30 years old. About 79\% (537) belonged to this age bracket. Male participants were slightly in the majority as 51\% (347) of the participants in the study were male while $49 \%$ (333) were female. Undergraduate students had a higher representation in the study as $70 \%$ of the participants in the study were undergraduate students while the remaining $30 \%$ were postgraduate students. The sample represented the different ethnic groups in Nigeria, particularly the three major groups. Igbo, Hausa and Yoruba constituted some 70\% of the participants (Hausa 18\%, Igbo 22\%, and Yoruba 30\%). Some $30 \%$ of the participants came from other minority ethnic nationalities in Nigeria. Eighty percent of the respondents reported to have used social media and mobile social networking applications. Ninety percent of the respondents reported to have used Facebook, $82 \%$ reported to use WhatsApp, $55 \%$ reported to have used $2 \mathrm{go}$, and $43 \%$ reported to used Twitter. 
Table 1. Regression about intention to participate in politics.

\begin{tabular}{|c|c|c|c|c|c|c|c|c|}
\hline Model & Variables & B & SE b & Beta & $\mathbf{T}$ & Sig & $\overline{\mathbf{R}^{2}}$ & $\overline{\text { Adjusted } R^{2}}$ \\
\hline \multirow{5}{*}{1} & Constant & 4.384 & .352 & & 12.453 & $.000 * * *$ & \multirow{5}{*}{.042} & \multirow{5}{*}{.033} \\
\hline & Age & -.144 & .068 & -.107 & -2.118 & $.035^{*}$ & & \\
\hline & Gender & -.073 & .108 & -.033 & -.675 & .500 & & \\
\hline & Level of study & -.372 & .180 & -.107 & -2.071 & 0.39 & & \\
\hline & Ethnicity & .149 & .059 & .127 & 2.532 & $0.12 *$ & & \\
\hline \multirow{8}{*}{2} & Constant & 4.480 & .515 & & 8.692 & $.000 * * *$ & \multirow{8}{*}{.218} & \multirow{8}{*}{.201} \\
\hline & Age & -.127 & .062 & -.094 & -2.041 & $.042 *$ & & \\
\hline & Gender & -.103 & .098 & -.047 & -1.052 & .293 & & \\
\hline & Level of study & .100 & .171 & .029 & .584 & .560 & & \\
\hline & Ethnicity & -.037 & .058 & -.032 & -.639 & .523 & & \\
\hline & Protest experience & -.797 & .123 & -.361 & .6487 & $.000^{* * *}$ & & \\
\hline & Political Efficacy & .146 & .052 & .149 & 2.822 & $.005^{*}$ & & \\
\hline & Social media use & -.092 & 309 & .213 & 2.381 & .053 & & \\
\hline
\end{tabular}

Note: ${ }^{* * *} \mathrm{p}<.001, * * \mathrm{p}<.005,{ }^{*} \mathrm{p}<.05$

\subsection{Protest Experience and Intention to Participate in Politics}

A hierarchical multiple regression analysis was conducted to address RQ1, that is, whether the intention to participate in politics could be predicted as a function of protest experience, political efficacy and social media use while gender, age, and ethnicity variables were controlled. In this regression analysis, intention to participate in politics was the criterion variable while gender, age, ethnicity, social media use and political efficacy were predictors.

From Table 1 above, the ten predictor variables explained $21.8 \%$ of the variance in intention to participate in political affairs, $\left(\mathrm{R}^{2}=.218\right.$, adjusted $\mathrm{R}^{2}=.201, \mathrm{~F}(9,672)=12.95$, $\mathrm{p}<.001)$. By Cohen's [17] conventions, a combined effect of this magnitude can be considered "medium" $\left(\mathrm{f}^{2}=.218 / 1\right.$ $.218=.22$ ). Of the five primary predictor variables, protest experience, and political efficacy uniquely contributed to the model: protest experience with $(\beta=-.361, \mathrm{t}(672)=2.822$, $\mathrm{p}<.001)$, and political efficacy, $(\beta=.149, \mathrm{t}(672)=6.487$, $\mathrm{p}<.05)$. The standardized beta values $(\beta)$ of the significant predictors show that political efficacy had a greater impact on intention to participate in politics than protest experience.

\subsection{Results of Semi-Structured Interviews}

Fifty three percent of the interview participants were female while forty seven percent were male. Undergraduates accounted for $60 \%$ of the interview participants while $40 \%$ of the participants were postgraduate students. Almost all participants that the researcher spoke to during the interviews mentioned, both implicitly and explicitly, the importance of offline and online protest in Nigeria. They argue that the protests have changed government's decision-making style in Nigeria. This sub-theme of government decision making style due to the protests is of relevance in this study as it relates not just to the importance of the protests, but also to perceived government accountability in Nigeria. A perceived accountability in the government's decision-making style due to protests would arguably improve political efficacy, decrease the perceived corruption level, and all these can lead to intention to participate in politics.

Participants spoke about government decision making style when answering the question about the role of social media in the success of protests in Nigeria and government accountability. There was a considerable overlap between the participants' comments about the role of social media to the success of protests, and government's decision-making style. Comments from the interview participants revealed that government decision making style now unlike before attempts to put the citizenry first and shows respect to the people. One of the participants revealed that:

... The Occupy Nigeria protest was an eye opener in the sense that government officials don't govern themselves, rather, they govern the citizens of the country. If they govern the citizens of the country, then the yearnings of the citizens should be heard. This was exactly what the Occupy Nigeria protest did for us as it made those in government to understand that governance is not about embezzlement of public fund but rather to deliver on the aspirations of the citizens.

As with the majority of his comments, this interview participant is elated that the protest in 2012 shaped the presidential media chat, a first of its kind as a mark of respect to the Nigerian people (the electorate) and a sign of change on how the leaders perceive the people. Another interview participant conveyed similar viewpoint. She explained how the then president conceded defeat to the incumbent, the first time this has happened in the history of Nigeria. She reasoned that prior to 2012; those in government can do whatever they liked without considering the people's wish. She believes that the protests from 2012 have changed such attitude from those in leadership:

I don't know if you heard the news concerning our last president. You know, when he conceded defeat. When he was conceding, he mentioned that he considered the lives of the people in Nigeria. Those words made me feel better because I realized that the government think about Nigerians now before doing anything. This was not previously there.

In the above comments, this participant pointed out that 
the then president, in his conceding speech, acknowledged that for the safety of the people and as a mark of respect to the electorate, he would not challenge the result of the election in the courts as such gesture would lead to ethnic war and bloodshed. The participant ended her comments with an appreciation of this type of attitude as being new, and good and that it "was not there before". Another interview participant perceived a change in how the government approaches policy making now compared to the way it was done prior to the protests. He remarked that government does not take decisions in a haste as they consult with the people to receive feedback. Due to their protests, this research participant believes that "the government does not make decisions in haste as they used to do". According to him, the government cannot wake up one morning and decide as "the government now consult widely to know how Nigerians will react to such a policy" This interview participant conclude that he understands Nigeria "have had a bit of a change in that aspect in Nigeria".

The participant's comments convey an understanding that things have improved. His comments are important because one of the issues that led to the 2012 protest and many more after was government's inability to consult widely and the suddenness of the announcements. With this participant's comments noting that sudden decisions have given way to a more consultative approach, it appears that he perceives change in the government's decision-making style as a result of the protests. Another participant stated that protests have caused Nigerian leaders to respect Nigerians and to put the common man into the affairs of the state. She stated that 'today, unlike before, government and leaders consult the people before making a law or a piece of policy. Occupy Nigeria has changed how Nigeria is run'. This participant's comments lend credence and are in unison with the comments of majority of the interview participants of this study. They believe that there has been a change of governing style from the government and perceive that the government respect the people now than prior to the 2012 when protests started in Nigeria.

From the data, it is apparent also that social media did two interrelated things for the participants. It provided a 'secure' debate platform and it encouraged them through the online comments to learn about the issues and to join the protests. To further reinforce the role that social media played in planning for the protests in Nigeria, the comments of another interview participant from the University of Lagos is pertinent. She stated that the reach of the internet and its ease of use helped them 'to achieve the little successes that they had'. She argued that social media really helped them during the protests as it enabled them send and receive messages about the protest, and how people are reacting to the protest. She indicated that social media platforms helped them and contributed immensely to the spreading of the protest stories and successes. Similarly, another interview participant from the Rivers State University talked about how social media helped them to plan and coordinate the protest in 2012, and how it made it problematic for the government to force them to stop talking about the subsidy removal. Without social media platforms, the protest could not have been that successful the interview participant argued. Social media made it difficult to coerce the people to stop talking about the protest or stop them from participating in the protest because the whole world was watching and reading what was happening in Nigeria.

From her comments, this interview participant alluded to the security of the internet and its reach helped the protesters online, and that these characteristics contributed to the success of the protests. She eulogized the role of social media and attributed the success of the protests to its technologies.

\section{Discussion}

This study employed a face-face paper survey and semistructured interviews to explore the impact of social media use, and protest experience in political participation and political efficacy formation among students in Nigeria. The study provides an important perspective regarding social media use and political participation from developing democracies such as Nigeria, previously lacking in extant research in political communication. Findings revealed that political efficacy, and protest experience, impact the intention to participate in politics. Similarly, the observed effects suggest that political efficacy was the strongest predictor of intention to participate in politics. This shows that participating in the protests and being politically efficacious impacts Nigerian student's political participation than using social media.

Although studies have identified that actively participating in the communication process of political information online 'positively impact efficacy' [45]; seeking information via social media is a positive and significant predictor of people's social capital and civic and political participatory behaviours, online and offline [20,47], and that the internet helps mobilize a sizable segment of the population not engaged in political affairs in any way outside of the virtual world. Findings from this study extend understanding of social media, protest experience and political efficacy roles in intentions to participate in politics in the future. This finding also supports the argument that social media use help increase the citizens' levels of political participation [13], 2011).

Regarding the difference (if any) between protest participants and non-protest participants on how they view government accountability, perceived corruption level, political efficacy and intention to participate in politics, results indicate that students who have joined a protest before, were politically efficacious, had greater intention to participate in politics, and perceived corruption level to be lower than in Nigeria than those who did not join any of the protests. This means that students with protest experience viewed Nigerian political credentials favourably and are disposed to joining politics in future. This finding illustrates the mobilizing effect of protest participation among students in Nigeria. 
Interview participants of this study perceived that there was a positive change in how the Nigerian government treats Nigerians due to the protests. They argued that government has become more accountable due to the protests. With social media use associated with intention to participate in politics in this study, the protests in turns, increased the participants' political efficacy. This according to the participants means that using social media technologies to deliberate about protests in Nigeria increase political efficacy of participants of such protests. The findings of Vitak and colleagues [77] partially resonate with this finding in that using online platforms for politics related issues predict other forms of political participation. However, this study has established that social media use is not the determinant factor but what one use social media for. In this study, those that use it for protest purposes become political more efficacious and yearns to join politics. The result also supports the argument that online exposure to political information is significantly associated with political efficacy, knowledge and participation [35].

Findings reveal that the results gained from the protests emboldened the student protest participants to have increased drive to participate in future political affairs. This explains the Nigerian students' political efficacy formation flowchart below. In this flowchart, the assumption is that Nigerian university students were not politically efficacious due to 'pluralistic ignorance' [65], caused by previous repressive regimes in Nigeria. However, hardship witnessed and campaigned through social media platforms on the results of government programs and policies during the protests in Nigeria led to anger contagion that swayed the people to protests in Nigeria (online or offline). During these protests, the protest participants witnessed in real time, the power of the people in a democracy as "stern" speaking government officials started begging and asking for dialogue. The paper argues that this brought the realization to the participants that political power rests with the people.

According to Figure 1 below, the realization that power rests with the people amplified the student protest participant's political efficacy [72]. The reverse is the case for those who did not participate in the protest. They appear to doubt their ability to oust any bad leader or make a change in Nigeria politically. This could explicate their lack of political efficacy. In this model, social media and to some extent mainstream media platforms are used as a deliberative space about contentious events, policies and programs. These deliberations help educate those who may not have known the intricacies about the policies and programs. This knowledge irks the participant to join online or offline protests. The success of such protests increases the participant's political efficacy as the participant now understands that him or her can play a part in bringing about political change [11]. However, when the student did not join the protests, the student may not have seen how much power that he or she possesses. This subdues the student's political efficacy formation.

Overall, these findings support the assertion that social media has a strong relationship with political participation and engagement among young people [39]. These results provide insights into the role of participatory media and prior protest experience in students process of becoming politically engaged. Research suggests that students' online political activity predicts other forms of political participation. Results from this study however, show that not only protest experience enhance political efficacy among Nigeria students but also predict participation in future politics.

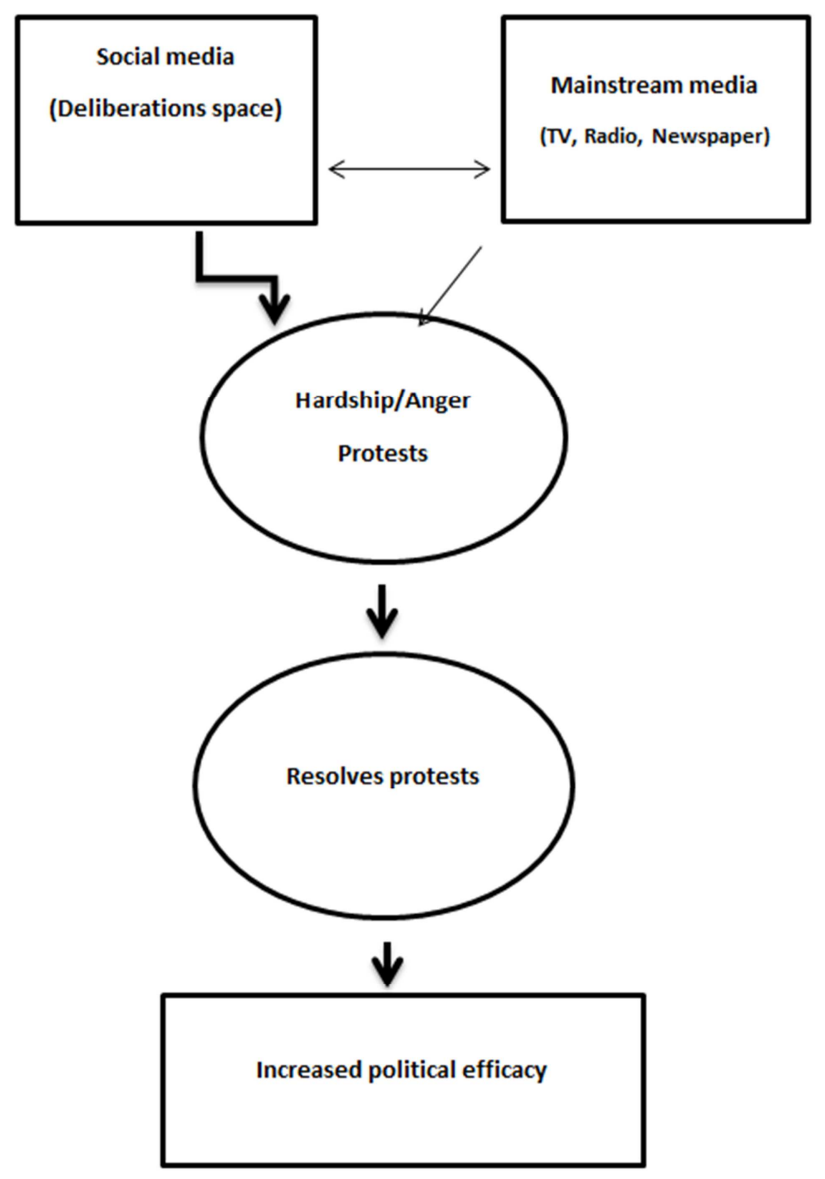

Figure 1. Flowchart of political efficacy formation among students in Nigeria.

\section{Conclusion}

This study examined the impact of social media use, protest experience and political participation and political efficacy formation. Based on the survey and semi-interview data, this study uncovered that protest experience, and political efficacy predicts intention to participate in politics among students in Nigeria but not social media use.

Result also reveals that students with protest experience perceived government to be accountable in Nigeria, more so, than those without protest experience. This study concludes that those with protest experience were more politically efficacious, had greater intention to participate in political affairs, and perceived corruption level to be lower than their peers without protest experience.

The results also reveal that protests experience changed 
how government officials perceive the people. Participants suggest that since they started protesting bad policies and programs, the government saw Nigerians as proactive and as a result consults with the people before making an important policy decision. This self-belief showed by the participants confirms the survey results, where protest experience increased both political efficacy and intention to participate in politics.

This study unpacks significant use of social media as well as protest experience in political participation among students in Nigeria. This study shows the mobilizing effects of protests to not only help in political participation at that point in time but to enhance future political participation. As stated above, this is significant as it deepens the understanding of Nigerian students' political participation and efficacy formation process. The study also adds a SubSaharan African voice in the global political communication and digital activism literature regarding the impact of social media use, protest experience in political and efficacy formation. In all, this paper illustrates that the experience of collective action as well as social media use increase the likelihood of further political participation as well as evaluations of the quality of governance.

The sample adopted has certain drawbacks which future studies should attempt to mend. While cross-sectional survey design enables a snapshot of a phenomenon, it is unable to explain the complete elements of causation [47, 57]. Sample from two universities in Nigeria might not be representative of Nigerian students. While it is unlikely to claim that this is representative sample, the ethnic mix of these two universities and the average age of participants of the study and number of participants can mitigate these shortcomings and allows inferences to be drawn. However, future examinations should consider an elaborate longitudinal and panel design that can account for shift in participants affective, conative, and cognitive dispositions. A probability sample representative of a wider Nigerian youth population is also necessary in future interrogations in order to amplify the generalization, and external validity of the result.

\section{References}

[1] Adegbola, O., \& Gearhart, S. (2019). Examining the Relationship Between Media Use and Political Engagement: A Comparative Study Among the United States, Kenya, and Nigeria. International Journal of Communication, 13, 12311251.

[2] Amadi, F. (2003). Errors in Nigerian Mass Media. Port Harcourt: Charles Worth.

[3] Amadi, F. (2006). Critical Issues in Nigerian Mass Media. Port Harcourt: Charles Worth.

[4] Baguma, J. (2014). Citizens' Advocacy for Public Accountability \& Democratic Engagement through ICT Convergence in Eastern Africa. In P. Parycek \& N. Eldelmann (Eds.), E-Democracy and Open Governement (pp. 449-462). Krems, Austria: Danube University.
[5] Bennett, W. L., \& Segerberg, A. (2011). Digital media and the personalization of collective action: Social technology and the organization of protests against the global economic crisis. Information, Communication \& Society, 14 (6), 770-799.

[6] Bennett, W. L., \& Segerberg, A. (2013). The logic of connective action: Digital media and the personalization of contentious politics. New York: Cambridge University Press.

[7] Bimber, B. (2001). Information and political engagement in America: The search for effects of information technology at the individual level. Political Research Quarterly, 54 (1), 5367.

[8] Bimber, B., Flanagin, A. J., \& Stohl, C. (2005). Reconceptualizing collective action in the contemporary media environment. Communication theory, 15 (4), 365.

[9] Breuer, A., \& Groshek, J. (2014). Online media and offline empowerment in post-rebellion Tunisia: An analysis of Internet use during democratic transition. Journal of Information Technology \& Politics, 11 (1), 25-44.

[10] Bryman, A. (2016). Social Research Methods (5th ed.). Oxford: Oxford university press.

[11] Campbell, A., Gurin, G., \& Miller, W. E. (1954). The voter decides. Oxford: Row, Peterson.

[12] Castells, M. (2012). Networks of outrage and hope: Social movements in the internet age. Cambridge: Polity Press.

[13] Christensen, H. S., \& Bengtsson, Å. (2011). The political competence of Internet participants: Evidence from Finland. Information, Communication \& Society, 14 (6), 896-916.

[14] Cleen Foundation. (2012). Fuel Subsidy Crisis in Nigeria. Retrieved from Lagos: www.cleenfoundation.blogspot.com.

[15] Clottey, P. (2012). Nigeria Strike to Proceed Monday Despite Court Order. Retrieved from http://www.voanews.com/content/nigeria-strike-to-proceedmonday-despite-court-order--136914433/159428.html.

[16] CNN. (2012). Nigerians Protest End of Fuel Subsidy. Retrieved https://edition.cnn.com/2012/01/09/world/africa/nigeriastrike/index.html.

[17] Cohen, J. (2013). Statistical power analysis for the behavioral sciences (Revised ed.). New York: Academic press.

[18] Cresswell, J. (2008). Research Design: Qualitative, Quantitative, and Mixed Method Approaches (3ed.). Thousand Oaks, Calif: Sage Publications.

[19] Dalton, R. J. (2017). The participation gap: Social status and political inequality. Oxford, UK: Oxford University Press.

[20] de-Zúñiga, H. G., Jung, N., \& Valenzuela, S. (2012). Social media use for news and individuals' social capital, civic engagement and political participation. Journal of ComputerMediated Communication, 17 (3), 319-336.

[21] Egbunike, N., \& Olorunnisola, A. (2015). Social media and the\# Occupy Nigeria Protests: Igniting or damping a Harmattan storm? Journal of African Media Studies, 7 (2), 141-164.

[22] Fenton, N., \& Barassi, V. (2011). Alternative media and social networking sites: The politics of individuation and political participation. The Communication Review, 14 (3), 179-196. 
[23] Freedom House. (2011). Countries at the Cross Roads: Methodology Questions. Retrieved from Online: https://freedomhouse.org/.

[24] Fuchs, C. (2014). Social media: A critical introduction. London: Sage.

[25] Gerbaudo, P. (2012). Tweets and the streets: Social media and contemporary activism. London: Pluto Press.

[26] Gerbaudo, P. (2016). Constructing Public Space| Rousing the Facebook Crowd: Digital Enthusiasm and Emotional Contagion in the 2011 Protests in Egypt and Spain. International Journal of Communication, 10, 254-273.

[27] Gibson, R. K., Lusoli, W., \& Ward, S. (2005). Online Participation in the UK: Testing a 'Contextualised' Model of Internet Effects1. The British Journal of Politics \& International Relations, 7 (4), 561-583.

[28] Hargittai, E., \& Shaw, A. (2013). Digitally Savvy Citizenship: The Role of Internet Skills and Engagement in Young Adults Political Participation around the 2008 Presidential Election. Journal of Broadcasting \& Electronic Media, 57 (2), 115-134.

[29] Hari, S. I. (2014). The Evolution of Social Protest in Nigeria: The Role of Social Media in the "\# OccupyNigeria" Protest. International Journal of Humanities and Social Science Invention, 3 (9), 33-39.

[30] Horrigan, J. B., Garrett, K., \& Resnick, P. (2004). The Internet and democratic debate: Pew Internet \& American Life Project

[31] Ibrahim, B. H. (2013). Nigerians Usage of Facebook during 2012 Occupy Nigeria Protests: a. Between Networked and Real Public Spheres. Science Journal of Researcher, 5 (7), 5564.

[32] Kanjo, C. (2011). Promoting E-Democracy and Citizen Participation through ICT Initiatives in Parliament: The Malawi Case. In M. Sobaci (Ed.), E-Parliament and ICTBased Legislation: Concept, Experiences and Lessons: Concept, Experiences and Lessons (pp. 312-326). Hershey: IGI.

[33] Kavanaugh, A., Kim, B. J., Perez-Quinones, M. A., Schmitz, J., \& Isenhour, P. (2008). Net gains in political participation: secondary effects of internet on community. Information, Communication \& Society, 11 (7), 933-963.

[34] Kaye, B. K., \& Johnson, T. J. (2002). Online and in the know: Uses and gratifications of the web for political information. Journal of Broadcasting \& Electronic Media, 46 (1), 54-71.

[35] Kenski, K., \& Stroud, N. J. (2006). Connections between Internet use and political efficacy, knowledge, and participation. Journal of Broadcasting \& Electronic Media, 50 (2), 173-192.

[36] Kombol, M. (2014). Uses of Social Media among Selected Labour Unions in Abuja during Nigeria's (January 2012) "Oil Subsidy" Removal Protests. Studies in Media and Communication, 2 (1), 102-114.

[37] Kvale, S. (1996). Interviews: An Introduction to Interviewing Qualitative Reseach London: Sage Publications.

[38] Levan, C., \& Utaka, P. (2012). Countries at the Crossroads: An Analysis of Democrtic Governance. In J. Dizard, Tucker, V., Walker, C (Ed.), Countries in Crossroads. New York: Freedom House.
[39] Loader, B. D., Vromen, A., \& Xenos, M. A. (2014). The networked young citizen: social media, political participation and civic engagement. Information, Communication \& Society, 17 (2), 143-150.

[40] Marshal, M., Gurr, T., \& Jaggers, K. (2013). Polity IV Project: Political Regime Characteristics and Transition. Retrieved from Online www.systemicpeace.org:

[41] Martin, J. D., Martins, R. J., \& Naqvi, S. (2018). Media use predictors of online political efficacy among internet users in five Arab countries. Information, Communication \& Society, 21 (1), 129-146.

[42] McChesney, R. W. (1995). Telecommunications, mass media, and democracy. London: Oxford University Press.

[43] McChesney, R. W. (2013). Digital disconnect: How capitalism is turning the Internet against democracy. New York: New Press.

[44] McChesney, R. W. (2015). Rich media, poor democracy: Communication politics in dubious times (3 ed.). New York, NY: The New Press.

[45] Moeller, J., De Vreese, C., Esser, F., \& Kunz, R. (2014). Pathway to political participation: The influence of online and offline news media on internal efficacy and turnout of first-time voters. American behavioral scientist, 58 (5), 689700.

[46] Munck, G. L., \& Verkuilen, J. (2002). Conceptualizing and measuring democracy Evaluating alternative indices. Comparative political studies, 35 (1), 5-34.

[47] Mustapha, L. K., Gbonegun, V. O., \& Mustapha, M. L. (2016). Social media use, social capital, and political participation among Nigerian university students. Tripodos. Facultat de Comunicació $i$ Relacions Internacionals Blanquerna.(39), 127-143.

[48] National Bureau of Statistics, N. (2020). Nigeria Population $2020 . \quad$ Retrieved from http://www.nigerianstat.gov.ng/index.php

[49] Norris, P. (2000). Democratic divide? The impact of the Internet on parliaments worldwide. Paper presented at the AMERICAN POLITICAL SCIENCE ASSOCIATION ANNUAL MEETING, Washington DC.

[50] Norris, P. (2002). Democratic Phoenix: Reiventing Political Activism. New York: Cambridge University Press.

[51] Norris, P. (2005). The impact of the Internet on political activism: Evidence from Europe. International Journal of Electronic Government Research (IJEGR), 1 (1), 19-39.

[52] Norris, P. (2007). Political activism: New challenges, new opportunities. In C. S. Boix, S (Ed.), The Oxford handbook of comparative politics (pp. 628-652). New York: Oxford University Press.

[53] Ogala, E., \& Ben, E. (2013). \#Occupy Nigeria: One Year later, the Gains, the Losses. Premium Times.

[54] Ogbondah, C. (1991). The pen is mightier than the "koboko": A critical analysis of the Amakiri case in Nigeria. Political Communication, 8 (2), 109-124.

[55] Ogbondah, C. (1994). Press freedom and political development in Africa. Africa Media Review, 8 (3), 1-39. 
[56] Ogbondah, C. (2000). Political repression in Nigeria, 19931998: A critical examination of one aspect of the perils of military dictatorship. Africa Spectrum, 35 (2), 231-242.

[57] Ognyanova, K., \& Ball-Rokeach, S. (2015). Political efficacy on the internet: A media system dependency approach. Communication, information technologies annual 9 (1), 3-27. doi: https://doi.org/10.1108/S2050-206020150000009001.

[58] Onwuegbuchi, C. (2012). How social media fuelled "Occupy Nigeria" protests. Nigeria Communications Week, 6.

[59] Oyesomi, K. O., Ahmadu, F. O., \& Itsekor, V. (2014). Facebook and Political Communication in the 2011 General Elections. Journal of Research on Humanities and Social Sciences, 4 (11), 1-9.

[60] Park, C. S., \& Karan, K. (2014). Unraveling the relationships between smartphone use, exposure to heterogeneity, political efficacy, and political participation: A mediation model approach. Asian Journal of Communication, 24 (4), 370-389.

[61] Putnam, R. D. (2000). Bowling Alone: The Collapse and Revival of American Community. New York: Simon \& Schuster.

[62] Ragauskas, E. (2014). The Internet and Democracy: Virtual Impacts on the Political Landscape. (PhD), University of Georgia, Georgia. Retrieved from https://athenaeum.libs.uga.edu/handle/10724/30600

[63] Robertson, S. P., Vatrapu, R. K., \& Medina, R. (2010). Off the wall political discourse: Facebook use in the 2008 US presidential election. Information Polity, 15 (1), 11-31.

[64] Scheufele, D. A., \& Nisbet, M. C. (2002). Being a Citizen Online New Opportunities and Dead Ends. The Harvard International Journal of Press/Politics, 7 (3), 55-75.

[65] Tufekci, Z., \& Wilson, C. (2012). Social media and the decision to participate in political protest: Observations from Tahrir Square. Journal of Communication, 62 (2), 363-379.

[66] Uwalaka, T. (2015). Nairaland and the Reconstruction of the Public Sphere in Nigeria. Paper presented at the The Australian and New Zealand Communication Association conference: Rethinking communication, space and identity, Queenstown, New Zealand.

[67] Uwalaka, T. (2016). Muzzling the Fifth Estate: An Analysis of the 2015 'Social Media' Bill in Nigeria. Paper presented at the Australian and New Zealand Communication Association Conference: Creating Space in the Fifth Estate, Newcastle. https://www.researchgate.net/publication/318671787_Muzzlin $\mathrm{g}$ the_Fifth_Estate_An_analysis_of_the_2015_'Social_Media' _Bill_in_Nigeria.

[68] Uwalaka, T. (2020). Clicktivism and Political Engagement in Nigeria. The Nigerian Journal of Communication, 17 (1) http://tnjc.org.ng/wpcontent/uploads/Vol17N1Full/Clicktivism-and-PoliticalEngagement-in-Nigeria.pdf.

[69] Uwalaka, T., Nwala, B., \& Amadi, C. (2020). Hashtag Activism: Exploring: The Church Must Vote Campaign in Nigeria, Covenant Journal of Communication, 7 (1). http://journals.covenantuniversity.edu.ng/index.php/cjoc/articl e/view/2124.
[70] Uwalaka, T. (2020). Leadership in digital activism: An example of Techno-Enthusiasts in Nigeria. Journal of Communication Research and Practice, 6 (3), 229-244.

[71] Uwalaka, T., (2019). Social Media and the rise of digital activism among students in Nigeria. Journal of Communication and Media Research, 11 (2), 15-27.

[72] Uwalaka, T. (2017). Mobile Internet and the Rise of Digital Activism among University Students in Nigeria. (Doctoral Thesis), University of Canberra.

[73] Uwalaka, T., Rickard, S., \& Watkins, J. (2018). Mobile social networking applications and the 2012 Occupy Nigeria protest. Journal of African Media Studies, 10 (1), 3-19.

[74] Uwalaka, T., \& Watkins, J. (2017). Social Media vs Mainstream Media: An Analysis of the 2012 Occupy Nigeria Protest. In L. Allen (Ed.), 6th Annual International Conference on Journalism \& Mass Communication (pp. 5968). Singapore Global Science and Technology Forum.

[75] Uwalaka, T., \& Watkins, J. (2018). Social Media as the Fifth Estate in Nigeria: An Analysis of the 2012 Occupy Nigeria Protest. African Journalism Studies, 39 (4), 22-41.

[76] Vanhanen, T. (2000). A new dataset for measuring democracy, 1810-1998. Journal of Peace Research, 37 (2), 251-265.

[77] Vitak, J., Zube, P., Smock, A., Carr, C. T., Ellison, N., \& Lampe, C. (2011). It's complicated: Facebook users' political participation in the 2008 election. Cyber Psychology, behavior and social networking, 14 (3), 107-114.

[78] Willnat, L., Wong, W. J., Tamam, E., \& Aw, A. (2013). Online media and political participation: The case of Malaysia. Mass Communication and Society, 16 (4), 557-585.

[79] Xenos, M., Vromen, A., \& Loader, B. D. (2014). The great equalizer? Patterns of social media use and youth political engagement in three advanced democracies. Information, Communication \& Society, 17 (2), 151-167.

[80] Xu, Q., \& Qi, L. (2014). Use of SNSs, political efficacy, and civic engagement among Chinese college students: Effects of gratifications and network size. International Journal of Interactive Communication Systems and Technologies (IJICST), 4 (1), 15-30.

[81] Yamamoto, M., Kushin, M. J., \& Dalisay, F. (2013). Social media and mobiles as political mobilization forces for young adults: Examining the moderating role of online political expression in political participation. New Media \& Society, 880-898.

\section{Biography}

Temple Uwalaka lectures at the School of Arts and Communication, Faculty of Arts and Design, University of Canberra, Australia. He teaches communication, marketing communication and journalism units to undergraduate and postgraduate students at the university. His research interests include digital activism, digital journalism, social marketing campaigns and the use of online and mobile media to influence political change. 